A. Karperien

J. N. van den Anker

P. H. Rothbarth

R. de Groot

\section{Case of the month: a newborn with tachypnoea and consolidation of the right lung}

$10^{9} / \mathrm{l}, \mathrm{WBC}$ count $10.9 \times 10^{9} / \mathrm{l}$ with $8 \%$ band forms, $33 \%$ neutrophils and $58 \%$ lymphocytes, serum CRP level $56 \mathrm{mg} / \mathrm{l}$ and capillary blood gas analysis pH 7.28, $\mathrm{PCO}_{2} 9 \mathrm{kPa}$, bicarbonate $32.1 \mathrm{mmol} / \mathrm{l}$, base-excess $+3.3 \mathrm{mmol} / \mathrm{l}$. A chest radiograph showed a lobar infiltrate in the right upper lobe. Bacteriological cultures of blood, sputum and CSF remained negative. The infant was treated with intravenous ampicillin and cefotaxim. When his clinical condition did not improve intravenous erythromycin was added. A new chest radiograph at day 11 showed complete consolidation of the right lung (Fig. 1).

The child was subsequently transferred to our hospital. On admission a moderately ill child was seen with tachypnoea (respiratory rate: $60 / \mathrm{min}$ ) and oxygen demand $(46 \%)$. The rectal temperature was $36.7^{\circ} \mathrm{C}$. Auscultation of the right lung revealed decreased breathsounds and rhonchi. Laboratory results included haematocrit $0.52 \mathrm{l} / \mathrm{l}$, platelet count $79 \times 10^{9} / 1$, WBC count $14.6 \times 10^{9} / 1$ and CRP level $56 \mathrm{mg} / \mathrm{l}$. Capillary blood gas analysis revealed $\mathrm{pH} 7.39, \mathrm{PCO}_{2}$ $7.3 \mathrm{kPa}$, base-excess $+7 \mathrm{mmol} / \mathrm{l}$. CSF analysis showed 12 cells $/ 3 \mathrm{~mm}^{3}$, glucose and protein levels $2.5 \mathrm{mmol} / \mathrm{l}$ and $84 \mathrm{mg} / 100 \mathrm{ml}$ respectively. A bronchoscopy with broncho-alveolar lavage was performed on day 11 . Pu- rulent secretion was seen in the right upper lobe.

Treatment was started with amoxicillin/clavulanic acid $(25 / 2.5 \mathrm{mg} / \mathrm{kg}$ qid), tobramycin (3 mg/kg once daily) and erythromycin $(5 \mathrm{mg} / \mathrm{kg}$ qid) intravenously. At the age of 14 days the patient developed an erythematous rash, which disappeared spontaneously after 1 day. Bacterial cultures remained negative. On day 19 results of viral cultures were obtained.

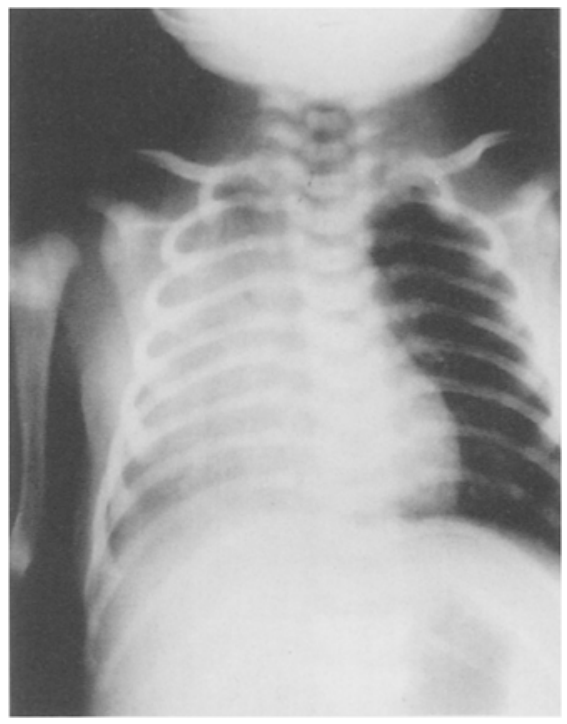

Fig. 1 Chest radiograph (A--P view) showing complete consolidation of the right lung 


\section{Diagnosis: \\ Herpes simplex \\ pneumonia in a newborn}

\section{Basis for diagnosis}

Viral eultures obtained from the broncho-alveolar fluid grew herpes simplex virus (ISS V) type 2. Cultures of CSF, nose and throat remained negative for HSV. High titres of IgM and $\lg G$ antibodies against HSV were detected by in direet immunofluorescence [6], indicating the acquisition of a recent HSV infection. (IgM 1:256 and $\operatorname{lgG} 1: 256$ on day 12 of life, $\operatorname{IgM} 1256$ and IgG 1:1024 on day 30 of life ). Liver and renal function tests were normal.

The patient was subsequently treated with intravehous acyclovir $(10 \mathrm{mg} / \mathrm{kg}$ tid $)$ during 12 days. His clinical condition improved, CRP levels retumed to normal. A chest radiograph on day 36 showed a small atelectasis in the right upper lobe. The patient left the hospital in good clinical condition on day 36. Neurological examination at that time revealed no abnormalities.

There was no history of maternal genital HSV infection. HSV cultures from cervix and vagina from the mother were not taken. However, serum of the nother showed no IgM antibodies (titre: $<1: 16)$ and a high level of $\lg G$ antibodies (titre: $1: 1024$ ).

\section{Discussion}

Neonatal HSV infection is a rare but serious infection with a high morbidity and mortality. The incidence has been estimated at 200-500 per 100000 live births in the USA and at 2 per 100000 in the United Kingdom [11]. In approximately $80 \%$ of neonatal HSV infections, the virus is transmitted during labour. Infection is due to transplacental spread in 5\% and is postnatally acquired in $15 \%$ [16].

Neonatal HSV infection may produce a variety of patterns of clinical disease. Localised infection of eye, mouth and throat is seen in $43 \%$, meningo-encephalitis is $34 \%$ and disseminated infection in $23 \%$ [17]. The mortality rate in these groups is $0 \%, 15 \%$ and $57 \%$ respectively [18].

The isolated occurrence of HSV pneumonia has occasionally been reported [1, 3-5, 7, 9, 10, 13, 14]. In most cases it is part of a disseminated syndrome with multi-organ failure and intravascular coagulation. Approximately $20 \%$ of infants with disseminated HSV infection have radiological evidence of pneumonitis or pleural effusion [7]. To date only 15 patients with primary HSV pneumonia with or without disseminated infection have been reported $[1,3-5,7$, $9,10,13,14]$. All patients presented with respiratory distress and abnormal chest radiographs within the first 10 days of life. In 8 of these newborns the correct diagnosis was suspected and therapy was started before or on the 5th day after onset of symptoms. Five of the patients survived. All other neonates with the exception of the one described above, died.

Clinically the diagnosis of HSV type 2 pneumonia is difficult. In only 1 of the 15 children could a history of prior HSV infection in the mother be obtained [14]. Only 3 of 14 previously described neonates had a vesicular rash $[5,7,10]$. Our patient had a erythematous rash on day 14 of life, which disappeared within $24 \mathrm{~h}$. The fact, that the virus culture was positive for HSV 2 after 7 days indicates the presence of a low virus load, since HSV usually demonstrates cytopathic changes after $1-2$ days. Furthermore it is conceivable, that some neutralization took place.

Hubbell et al. [7] have suggested to start antiviral treatment when the aetiology of the pneumonia is unknown and one of the following parameters is present: thrombocytopenia, evidence of disseminated intravascular coagulation, elevated liver function tests, a positive result in a rapid screening test for $\mathrm{HSV}$, lymphocytic pleiocytosis of the CSF, development of vesicular skin lesions or further deterioration in clinical status during treatment with antibiotics. Our patient illustrates the usefulness of this advice. The progression of the pneumonia despite antibiotic treatment and a prior vesicular rash should have led to an earlier start of therapy with acyclovir.

Approximately $50 \%$ of infants from mothers with primary genital infection by HSV become infected, whereas less than $5 \%$ of infants exposed to recurrent maternal infection at the time of delivery are infected [2]. This is mainly due to the fact that in recurrent HSV infections the cervix is less frequently infected. Furthermore, HSV is present in the genital tract in lower titres and for a shorter time during a recurrent infection than during a primary infection [12]. The role of neutralizing antibodies in influencing the attack rate and clinical manifestations remains controversial $[2,8,12,15]$. In a study of 55 patients by Prober et al. [12] absence of neutralizing antibodies to HSV was associated with the onset of symptoms of HSV infection during the 1st week of life and with disseminated infection. Infants with neutralizing antibodies to HSV tended to have localised infections at an older age. However Kahlon and Whitley [8] could not confirm a significant correlation between antibody status and clinical outcome.

We suggest that a low virus load in combination with transplacental passage of neutralizing antibodies has 
resulted in a mild infection in our patient, allowing complete recovery despite a substantial delay in treatment.

\section{References}

1. Andersen RD (1987) Herpes simplex virus infection of the neonatal respiratory tract. Am J Dis Child 141:274276

2. Arvin AM (1991) Relationships between maternal immunity to herpes simplex virus and the risk of neonatal herpesvirus infection. Rev Infect Dis 13 (S11):953-956

3. Barker JA, Scott DM, Glenn DJ, Marvin SK, Rawlings JS (1990) Primary neonatal herpes simplex virus pneumonia. Pediatr Infect Dis J 9:285-289

4. Campbell AN, O'Driscoll MC, Robinson DL, Read SE (1983) A case of neonatal herpes simplex with pneumonia. Can Med Assoc J 129:725-726

5. Greene GR, King D, Romansky SG, Marble RD (1983) Primary herpes simplex pneumonia in a neonate. Am J Dis Child 137:464-465
6. Hekker AC, Brand-Saathof B, Vis J, Meijers RC (1979) Indirect immunofluorescence test for detection of $\operatorname{IgM}$ antibodies to cytomegalovirus. J Infect Dis $140: 596-600$

7. Hubbel C, Dominguez R, Kohl S (1988) Neonatal herpes simplex pneumonitis. Rev Infect Dis 10:431-438

8. Kahlon J, Whitley R. (1988) Antibody response of the newborn after herpes simplex virus infection. $J$ Infect Dis 158:925-933

9. Lisauer TJ, Shaw PJ, Underhill G (1984) Neonatal herpes simplex pneumonia. Arch Dis Child 59:668-670

10. Mascola L, Cable DC, Walsh P, Guinan ME (1984) Neonatal herpes simplex virus death manifested as rapidly progressive pneunomia. Clin Pediatr 23:400-403

11. McKintosh D, Isaacs D (1992) Herpes simplex virus infection in pregnancy. Arch Dis Child 67:1137-1138

12. Prober CG, Sullender WM, Yasukawa LL, Au DS, Yeager AS, Arvin AM (1987) Low risk of herpes simplex virus infections in neonates exposed to the virus at the time of vaginal delivery to mothers with recurrent genital herpes simplex virus infections. $\mathrm{N}$ Engl $\mathrm{J}$ Med 316:240-244
13. Rawlings JS, Krober MS, Aamodt LW (1989) Imaging case of the month: neonatal herpes simplex virus phneumonia. Am J Perinatol 6:304 306

14. Stewart DL, Cook LN, Rabalais GP (1993) Successful use of extracorporeal membrane oxygenation in a newborn with herpes simplex virus pneumonia. Pediatr Infect Dis J 12:161-162

15. Toltzis $P$ (1991) Current Issues in neonatal herpes simplex virus infection. Clin Perinatol 18: 193-208

16. Whitley RJ, Arvin AM (1995) Herpes simplex virus infections. In: Remington JS, Klein JO (eds) Infectious diseases of the fetus and newborn infant. Saunders, Philadelphia pp 354-372

17. Whitley RJ, Corey L, Arvin A, Lakeman FD, Sumaya CV, Wright PF, Dunkle LM, Steele RW, Soong SI, Nahmias AJ, Alford CA, Powell DA, San Joaquin V (1988) Changing presentation of herpes simplex virus infection in neonates. J Infect Dis 158: 109-116

18. Whitley R, Arvin A, Prober C, Corey L, Burchett S, Plotkin S, Starr S, Jacobs R, Powell C, Nahmias A, Sumaya C, Edwards K, Alford C, Caddell G, Soong SJ (1991) Predictors of morbidity and mortality in neonates with herpes simplex virus infections. N Engl J Med 324:450-454 